\title{
IMPLEMENTASI PENGADAAN TANAH UNTUK PEMBANGUNAN JALAN TOL MANADO-BITUNG DI KABUPATEN MINAHASA UTARA
}

\author{
Yandry Deby Ratu Rory \\ Charles R. Ngangi \\ Melsje Yellie Memah
}

\begin{abstract}
This study aims to describe (1) implementation and (2) mechanism of land acquisition compensation for Manado-Bitung Toll Road development in North Minahasa Regency based on Law No. 2 Year 2012. The research was conducted on the object of Manado-Bitung Toll Road development of North Minahasa Regency. The study conducted from October 2017 to April 2018. The method used in this research is descriptive qualitative method. Determination of sample method used purposive sampling method. The research found that (1) in the process of land procurement implementation at the stages: (a) planning and (b) the preparation stage were not implemented properly. Initial data not available, multiple location revision fixes, and public consultations not implemented; (c) at the implementation stage by task force $A$ and task force $B$ are constrained by the absence of landowners, no land boundary markers, also at certain track terraces or point of the middle of the road there are coordinate differences, lack of building and plant appraisers, and land ownership issues; at stage (d) the delivery of the results has not yet been delivered as there are still areas of land that have not been released yet. As for (2) The mechanism for appraisal of compensation is found in stage (a) Determination of Land Appraisal by the Chief of Land Acquisition Officer in the implementation of appraisal by appraissal person there is delay of nominative submission; at stage (b) deliberations that occur are only limited to the determination of the form of indemnity and not the determination of the value of the indemnity. Whereas the determination of compensation value based on deliberation can prevent the occurrence of disagreement which will potentially the occurrence of dispute to the court can even cause riot, third stage (c) there is a consignment for compensation in court due to the existence of parcels that have no agreement in terms of the amount of compensation and still there dispute over land ownership.
\end{abstract}

Keywords: land procurement, consignment, Highway, Manado-Bitung, North Minahasa District.

Penelitian ini bertujuan mendeskripsikan (1) implementasi dan (2) mekanisme penilaian ganti rugi pengadaan tanah untuk pembangunan Jalan Tol Manado-Bitung di Kabupaten Minahasa Utara berdasarkan UU No 2 Tahun 2012. Penelitian dilakukan pada objek pembangunan Jalan Tol Manado-Bitung Kabupaten Minahasa Utara. Waktu penelitian berlangsung dari bulan Oktober 2017 sampai April 2018. Metode yang digunakan dalam penelitian ini adalah metode deskriptif kualitatif. Penentuan sampel menggunakan metoda purposive sampling. Hasil penelitian menunjukkan bahwa pada (1) proses implementasi pengadaan tanah pada tahapan: (a) perencanaan dan (b) tahapan persiapan tidak terlaksana sebagaimana mestinya. Data awal tidak tersedia, beberapa kali revisi penetapan lokasi, dan konsultasi publik tidak dilaksanakan; (c) pada tahapan pelaksanaan oleh satgas A dan satgas B terkendala dengan ketidak hadiran pemilik tanah, tidak terpasangnya patok batas bidang tanah, juga pada titik tengah jalan sebagai as jalan tertentu terdapat perbedaan koordinat, kurangnya tenaga penilai bangunan dan tanaman, serta permasalahan terkait kepemilikan tanah; pada tahap (d) penyerahan hasil ternyata belum dapat diserahkan karena masih ada bidang-bidang tanah yang belum dibebaskan. Sedangkan untuk (2) Mekanisme penilaian ganti rugi ditemukan pada tahap (a) Penetapan Penilai Tanah oleh Ketua Pelaksana Pengadaan Tanah ternyata dalam pelaksanaan penilaian oleh Penilai Tanah (Appraisal) terdapat keterlambatan penyerahan nominative; pada tahap (b) musyawarah yang terjadi hanya terbatas pada penetapan bentuk ganti rugi dan bukan penetapan nilai ganti rugi. Padahal penetapan nilai ganti rugi berdasarkan musyawarah dapat menghindarkan terjadinya ketidak sepakatan yang akan berpotensi terjadinya sengketa sampai ke pengadilan bahkan dapat menimbulkan kerusuhan, tahap ketiga (c) terjadi penitipan biaya ganti rugi (konsinyasi) di pengadilan karena adanya bidang tanah yang belum ada kesepakatan dalam hal besarnya ganti rugi dan masih adanya sengketa dalam hal kepemilikan tanah.

Kata kunci: pengadaan tanah, konsinyasi, jalan tol, Manado-Bitung, Kabupaten Minahasa Utara. 


\section{PENDAHULUAN}

\section{Latar Belakang}

Tujuan pembangunan nasional dilaksanakan untuk mewujudkan tujuan nasional seperti termaktub dalam Pembukaan UUD 1945 alinea IV, yaitu melindungi segenap bangsa Indonesia dan seluruh tumpah darah Indonesia, memajukan kesejahteraan umum, mencerdaskan kehidupan bangsa, dan ikut melaksanakan ketertiban dunia yang berdasarkan kemerdekaan, perdamaian abadi, dan keadilan sosial serta mewujudkan citacita bangsa. Pembangunan dilaksanakan untuk membangun manusia Indonesia seutuhnya dan didalamnya memberikan manfaat bagi seluruh rakyat Indonesia.

Pelaksanaan pembangunan bersentuhan langsung dengan sumber daya yang sangat berpengaruh terhadap hajat hidup orang banyak yaitu tanah. Tanah merupakan sumber daya alam yang sangat penting untuk kehidupan umat manusia, semua kegiatan manusia dan pembangunan memerlukan tanah.

Bagi Bangsa Indonesia tanah adalah karunia Tuhan Yang Maha Esa dan merupakan kekayaan nasional, hubungan antara bangsa Indonesia dengan tanah bersifat abadi. Pengelolaan sumber daya tanah harus dilaksanakan dengan aturan dan perencanaan yang baik agar tidak menimbulkan permasalahan. Perencanaan dan pengaturan mengenai penguasaan dan kepemilikan tanah serta pengelolaannya harus dipersiapkan dengan matang demi tercapainya kemakmuran rakyat.

Pembangunan strategis untuk kepentingan umum yang menjadi perhatian pemerintah di Provinsi Sulawesi Utara antara lain : Pembangunan Jalan Tol ManadoBitung, Pembangunan Waduk Kuwil, Pembangunan Waduk Lolak, Pembangunan Kawasan Ekonomi Khusus Kauditan Bitung Kema.

Pembangunan Jalan Tol Manado-Bitung sedang diupayakan dan ditargetkan beroperasi pada Tahun 2019. Jalan tersebut diharapkan nantinya akan meningkatkan perekonomian antar kabupaten kota khususnya dalam pengembangan Kawasan Ekonomi Khusus (KEK). Disamping itu juga di Jalan Tol Manado-Bitung akan menghubungkan akses antara daerah-daerah di Sulut yang akan kepelabuhan internasional Bitung, yang kini menjadi salah satu primadona dalam bidang pelayaran, yang diharapkan nantinya akan memudahkan masyarakat untuk ke Bitung, karena jarak tempuh akan lebih cepat.

Upaya dan target pembangunan Jalan Tol Manado-Bitung menemui kendala dilapangan yang sifatnya sangat fundamental terkait dengan masalah pembebasan lahan. Permasalahan pembebasan lahan atau pengadaan tanah tersebut lebih disebabkan karena adanya perbedaan harga antara yang ditetapkan oleh pemerintah dengan yang diinginkan oleh masyarakat pemilik hak atas tanah.

Pada pra-penelitian yang dilakukan, ditemukan bahwa perencanaan dan persiapan terkait pengembangan Jalan Tol ManadoBitung yang dilakukan oleh pemerintah mengalami kendala dalam hal pengadaan tanah. Hal tersebut dapat tergambarkan dari telah terjadinya beberapa kali mengalami perubahan dalam penetapan lokasi pengadaan tanah untuk pembangunan. Penyebabnya ialah belum ditemukannya kata sepakat terkait ganti rugi antara nilai yang ditetapkan oleh pemerintah dengan nilai yang diharapkan oleh pemilik lahan, sehingga untuk melanjutkan pembangunan yang telah direncanakan maka penetapan lokasi harus dipindahkan. Namun pemindahan lokasi untuk pembangunan bukanlah sebuah solusi, karena meskipun telah melakukan pemindahan lokasi, masalah nilai ganti rugi tetaplah menjadi masalah klasik yang selalu ditemukan di lapangan.

Berdasarkan uraian yang telah dikemukakan diatas, maka peneliti merasa perlu untuk melakukan penelitian tentang proses pengadaaan tanah untuk pembangunan jalan tol dalam rangka dalam perencanaan wilayah. Tujuan dari penelitian ini ialah untuk 
mengetahui dan menggambarkan proses perencanaan dan penetapan lokasi dalam tahapan perencanaan dan tahapan persiapan, pelaksanaan dan penyerahan hasil pengadaan tanah dalam pembangunan Jalan Tol ManadoBitung serta mengkaji proses ganti rugi lahan milik masyarakat.

\section{Rumusan Masalah} adalah:

Rumusan masalah dalam penelitian ini

1. Bagaimana implementasi pengadaan tanah pada pembangunan Jalan Tol Manado-Bitung di Kabupaten Minahasa Utara berdasarkan UU No 2 Tahun 2012?

2. Bagaimana mekanisme ganti rugi pengadaan tanah pembangunan Jalan Tol Manado-Bitung di Kabupaten Minahasa Utara?

\section{Tujuan Penelitian}

Tujuan dari penelitian ini untuk:

1. Menganalisis implementasi pelaksanaan pengadaan tanah untuk kepentingan umum pembangunan Jalan Tol ManadoBitung di Kabupaten Minahasa Utara.

2. Menganalisis mekanisme penilaian ganti rugi dalam pengadaan tanah pada pembangunan Jalan Tol Manado-Bitung di Kabupaten Minahasa Utara.

\section{Manfaat Penelitian}

1. Manfaat Akademik

a. Diharapakan penelitian ini dapat memberikan kontribusi ilmiah, pengetahuan dan pengalaman dalam mengkaji pengadaan tanah dalam pengembangan Jalan Tol ManadoBitung di Kabupaten Minahasa Utara.

b. Dapat menambah literatur bahan kajian penelitian terkait pengadaan tanah untuk kepentingan umum bagi peneliti-peneliti selanjutnya.

\section{Manfaat Praktis}

a. Sebagai gambaran untuk memecahkan masalah-masalah yang berhubungan dengan pelaksanaan iventarisasi dan identifikasi dalam tahapan pengadaan tanah bagi kepentingan umum. b. Sebagai bahan masukan kepada Pemerintah Provinsi Sulawesi Utara dan Pemerintah Kabupaten Minahasa Utara dalam pengadaan tanah bagi pembangunan untuk kepentingan umum.

\section{METODE PENELITIAN}

\section{Jenis Penelitian}

Penelitian ini menggunakan metode deskriptif, di mana data dikumpulkan, dianalisis dan dideskripsikan dengan menggunakan pendekatan kualitatif. Pendekatan kualitatif menggambarkan tanggapan informan terhadap pelaksanaan ganti rugi. Untuk mengetahui tanggapan informan maka peneliti menggunakan pedoman wawancara yang berisi pertanyaan-pertanyaan penelitian. Pertanyaanpertanyaan tersebut didasarkan pada aspekaspek yang diteliti. Pada penelitian ini, aspekaspek yang diteliti, yaitu: pendekatan dalam implementasi pengadaan tanah, proses ganti rugi, penilaian dalam ganti rugi, bentuk ganti rugi dan besaran ganti rugi.

\section{Lokasi dan Waktu Penelitian}

Penelitian dilakukan pada objek pembangunan Jalan Tol Manado-Bitung Kabupaten Minahasa Utara. Waktu penelitian berlangsung sejak bulan Oktober 2017 - April 2018.

\section{Teknik Pengumpulan Data}

Teknik yang digunakan dalam pengumpulan data dilakukan dengan beberapa tahap yang meliputi:

\section{Wawancara Mendalam}

Wawancara mendalam dilakukan oleh peneliti melalui tahapan-tahapan sebagai berikut:

a. Planning: Wawancara mendalam dilakukan oleh peneliti di awali dengan melakukan perencanaan dengan beberapa langkah, yaitu penetapan informan yang diwawancarai, penetapan materi wawancara dalam bentuk pertanyaanpertanyaan, penetapan media wawancara yaitu berupa alat perekam dan alat tulis- 
menulis, serta penetapan tempat dan waktu untuk kegiatan wawancara.

b. Appointment: Setelah itu, peneliti melakukan komunikasi untuk membuat janji jadwal pertemuan dengan informan, dengan terlebih dahulu peneliti menjelaskan maksud dan tujuan dari wawancara.

c. Implementation: Dalam melakukan wawancara mendalam dengan informan, peneliti menggunakan pedoman wawancara yang berisi pertanyaanpertanyaan terkait dengan tujuan penelitian. Peneliti lebih memilih tidak menggunakan pertanyaan-pertanyaan secara terstruktur tetapi tetap mengacu pada pedoman wawancara yang berisi pertanyaan-pertanyaan besar sesuai dengan tujuan yang ingin dicapai dalam penelitian.

d. Pengamatan Berpartisipasi

Pengamatan berpartisipasi dilakukan oleh peneliti melalui tahapan-tahapan sebagai berikut:

2. Planning: Dalam tahap perencanaan ini, langkah pertama yang dilakukan oleh peneliti ialah menetapkan tujuan dari pengamatan yaitu berupa informasi yang dibutuhkan oleh peneliti. Setelah penetapan tujuan telah dilakukan, maka langkah selanjutnya ialah penetapan lokasi dan waktu pengamatan. Lokasi yang menjadi sasaran peneliti ialah di tempat-tempat berlangsungnya kegiatan yang berkaitan dengan pengadaan tanah. Implemetation: Dalam tahap pelaksanaan ini, peneliti lebih memposisikan diri sebagai seorang insider. Pada proses pengamatan berpartisipasi ini, peneliti hanya mengamati situasi dan kondisi yang berkaitan dengan pengadaan tanah. Setiap hal terjadi di tempat pengamatan, kemudian dicatat oleh peneliti.

3. Studi Dokumen

Pada penelitian ini, peneliti melakukan studi dokumen terhadap semua hal yang terkait dengan penelitian ini, seperti dokumen resmi mengenai Undang-Undang Pengadaan Tanah Untuk Kepentingan Umum, serta peraturan-peraturan lainnya yang memiliki keterkaitan.

\section{Sumber Data}

Data yang diperoleh bersumber dari data primer dan data sekunder. Data primer diperoleh langsung dari lapangan melalui informan yang telah ditentukan, sedangkan data sekunder diperoleh melalui instansi atau lembaga-lembaga terkait seperi Badan Pertanahan Nasional Provinsi Sulawesi Utara, Balai Jalan Nasional Propinsi Sulawesi Utara dan instansi lainnya.

\section{Informan Penelitian}

Penentuan sampel dilakukan secara purposive sampling, yaitu teknik penentuan sampel dengan pertimbangan tertentu. Penentuan informan dengan teknik purposive sampling merupakan cara penentuan informan yang berdasarkan atas tujuan dan pertimbangan peneliti yang berhubungan dengan informan yang dianggap memiliki informasi dan mengetahui masalah yang diteliti. Penentuan informan secara rinci dapat terlihat sebagai berikut:

1. Bapak Fredy A. Kolintama, ST, MSi, selaku Kepala Kantor Wilayah Badan Pertanahan Nasional Provinsi Sulawesi Utara/ Ketua Pelaksana Pengadaan Tanah Jalan Tol Manado-Bitung.

2. Bapak Samsudin Kono, selaku Sekretaris Pelaksana Pengadaan Tanah Jalan Tol Manado-Bitung.

3. Bapak Adri Rotinsulu, SH, selaku ketua satgas A Pengadaan Tanah Jalan Tol Manado-Bitung.

4. Ibu Mareyke Lukas, SH, selaku Sekretaris Pengadaan Tanah Jalan Tol Manado-Bitung.

5. Bapak Rio Yani Mangimpis, S.SiT, selaku Kuasa Ketua Pelaksana Pengadaan Tanah Jalan Tol Manado-Bitung.

6. Bapak Weynni Paulce Davidson Mawey, selaku Pejabat Pembuat Komitmen Pengadaan Tanah Jalan Tol Manado-Bitung.

7. Bapak Darwadi yang bekerja bagian inpeksi lapangan di Kantor Jasa Penilai Publik SIH WIRAHADI \& REKAN, selaku salah satu Penilai Tanah pengadaan tanah Jalan Tol Manado-Bitung.

8. Bapak Jemi Kalengkongan, selaku Hukum Tua Desa Maumbi juga sebagai pemilik 
tanah terkena kegiatan pembangunan Jalan Tol Manado-Bitung.

9. Perwakilan masyarakat yang menolak ganti rugi pengadaan tanah Jalan Tol ManadoBitung.

\section{Teknik Analisis Data}

Dalam penelitian ini, data yang telah peneliti kumpulkan akan dianalisis melalui tahapan sebagai berikut:

1. Data yang telah dikumpulkan, selanjutnya disalin dalam bentuk tertulis berdasarkan masing-masing informan.

2. Setelah itu, peneliti mengorganisasikannya dalam satuan-satuan teks yang saling berhubungan dari lintas informan.

3. Atas dasar satuan-satuan teks tersebut, selanjutnya peneliti melakukan description, yaitu menggambarkan secara rinci mulai dari lokasi penelitian yaitu situasi dan kondisi Kabupaten Minahasa Utara berdasarkan geografis, demografis, ekonomi dan sosial budayanya.

4. Setelah tahapan deskriptif selesai dilakukan, kemudian peneliti membangun sebuah tema berdasarkan sejumlah kecil masalahmasalah (sub-kasus) yang diperoleh dari pengumpulan data baik melalui wawancara mendalam, pengamatan berpartisipasi maupun studi dokumentasi. Tahap pertama, peneliti mengidentifikasi permasalahan dan kompleksitas dari masing-masing sub-kasus yang ada. Tahap kedua, peneliti membuat tema pada setiap sub-kasus yang ada untuk menemukan tema secara umum. Setelah analisis tema selesai dilakukan, maka diberikan penegasan (assertion) atau penafsiran mengenai makna dari kasus berdasarkan tema yang ada.

5. Berpijak pada sub-kasus yang telah dirangkum dalam sebuah tema yang telah ada, kemudian peneliti memberikan makna terhadap data tersebut. Data yang telah dimaknai kemudian dihubungkan dengan pendapat ahli, teori, serta penelitianpenelitian sebelumnya. Data yang telah dideskripsikan, diklasifikasikan, dan ditafsirkan selanjutnya disajikan dan divisualisasikan dengan pemodelan sebagai bentuk abstraksi dari data hasil penelitian.

\section{HASIL DAN PEMBAHASAN}

\section{Gambaran Umum Daerah Penlitian}

\section{Letak, Luas dan Wilayah Administrasi Pemerintahan}

Minahasa Utara adalah salah satu Kabupaten di Provinsi Sulawesi Utara. Ibukota Kabupaten Minahasa Utara adalah Airmadidi, berjarak sekitar $35 \mathrm{~km}$ dari Manado, Ibukota Provinsi Sulawesi Utara. Adapun batas-batasanya adalah sebagai berikut :

a. Sebelah utara berbatasan dengan Kabupaten Sangihe Talaud, Laut Sulawesi dan Laut Maluku

b. Sebelah Timur berbatasan dengan Kota Bitung

c. Sebelah Selatan berbatasan dengan Kabupaten Minahasa

d. Sebelah Barat berbatasan dengan Kota Manado

Luas Kabupaten Minahasa Utara adalah $875,70 \mathrm{~km}^{2}$. Sebagian wilayah Minahasa Utara memiliki topografi berbukit-bukit dan lereng, diantaranya terdapat Gunung Klabat (1.995 meter). Kabupaten Minahasa Utara berdasarkan pembagian wilayah administrative pemerintah daerah dibagi dalam 10 kecamatan dan 131 desa/kelurahan dirinci 125 desa dan 6 kelurahan. Dipimpin seorang bupati tingkat kecamatan dipimpin oleh camat dan pada tingkat desa/kelurahan dipimpin oleh seorang Hukumtua/lurah.

Tabel 1. Luas Wilayah Menurut Kecamatan di Kabupaten Minahasa Utara, 2015

\begin{tabular}{lcc}
\hline Kecamatan/District & $\begin{array}{c}\text { Luas/Total Area } \\
\mathbf{k m}^{2}\end{array}$ & $\%$ \\
\hline Kema & 78,76 & 7,44 \\
Kauditan & 108,20 & 10,21 \\
Airmadidi & 86,66 & 8,18 \\
Kalawat & 39,03 & 3,68 \\
Dimembe & 166,43 & 15,71 \\
Talawaan & 82,51 & 7,79 \\
Wori & 90,7 & 8,56 \\
Likupang Barat & 104,29 & 9,85 \\
Likupang Timur & 290,84 & 27,46 \\
Likupang Selatan & 11,82 & 1,12 \\
\hline Jumlah / Total & 1059,24 & 100,00 \\
\hline
\end{tabular}


Dalam Tabel 1 memperlihatkan bahwa kecamatan yang paling luas wilayahnya ialah Kecamatan Likupang Timur dan kecamatan yang memiliki wilayah yang paling kecil adalah Kecamatan Likupang Selatan.

Tabel 2. Jumlah Desa/Kelurahan menurut Kecamatan Tahun 2016

\begin{tabular}{lccc}
\hline \multicolumn{1}{c}{ Kecamatan } & Desa & Kelurahan & $\begin{array}{c}\text { Satuan } \\
\text { Lingkungan } \\
\text { Setempat } \\
\text { (SLS) }\end{array}$ \\
\hline Kema & 10 & - & 73 \\
Kauditan & 12 & - & 135 \\
Airmadidi & 3 & 6 & 81 \\
Kalawat & 12 & - & 100 \\
Dimembe & 11 & - & 83 \\
Talawaan & 12 & - & 80 \\
Wori & 20 & - & 129 \\
Likupang Barat & 20 & - & 90 \\
Likupang Timur & 18 & - & 83 \\
Likupang Selatan & 7 & - & 32 \\
\hline Jumlah / Total & 125 & 6 & 886 \\
\hline
\end{tabular}

Berdasarkan data dalam Tabel 2 Kecamatan Wori dan Kecamatan Likupang Barat memiliki jumlah desa yang terbanyak yaitu 20 desa sedangkan Kecamatan Airmadidi walaupun jumlah desanya 3 tapi memiliki 6 kelurahan.

\section{Implementasi Pengadaan Tanah Pembangunan Jalan Tol Manado-Bitung}

Pembangunan Jalan Tol Manado-Bitung diharapkan dapat meningkatkan perekonomian masyarakat Sulawesi Utara khususnya masyarakat di Kota Manado dan Bitung yang terdampak langsung dari pembangunan jalan tol tersebut. Diharapkan juga akan mempersingkat waktu tempuh angkutan darat dari Manado ke Kota Pelabuhan Bitung dan sebaliknya dari Kota Bitung ke Kota Manado. Jalan Tol Manado-Bitung direncanakan dibangun dengan jarak $39 \mathrm{~km}$ yang terbagi 4 tahap :

1. Tahap 1, 0-7 km,

2. Tahap 2,7-14 km,

3. Tahap 3, 14-25,5 km,

4. Tahap 4, 25,5-39 km,

Proses pengadaan tanah Manado-Bitung dilaksanakan berdasarkan Perpres Nomor 36 Tahun 2005 Jo Perpres Nomor 65 Tahun 2006 didalamnya antara lain mengatur penentuan nilai ganti rugi ditetapkan oleh Panitia Pengadaan Tanah yang dimusyawarakan dengan pemilik tanah. Setelah diundangkan Undang-undang No. 2 Tahun 2012 tentang Pengadaan Tanah Bagi Pembangunan Untuk Kepentingan Umum, Perpres 71 Tahun 2012 Tentang Penyelenggaraan Pengadaan Tanah Bagi Pembangunan Untuk Kepentingan Umum, Perpres 40 Tahun 2014 Tentang Perubahan Atas Peraturan Presiden No. 71 Tahun 2012 Jo Perpres No. 99 Tahun 2014 Tentang Perubahan Kedua Atas Peraturan Presiden Nomor 71 Tahun 2012, Perpres No. 30 Tahun 2015 Tentang Perubahan Ketiga Atas Peraturan Presiden No. 71 Tahun 2012, Perpres No. 148 Tahun 2015 Tentang Perubahan Keempat Atas Peraturan Presiden No. 71 Tahun 2012. Berdasarkan Perpres 99 Tahun 2014 yang antara lain mengatur tentang proses pengadaan tanah yang belum selesai sampai dengan tanggal 31 Desember 2014, pengadaannya diselesaikan berdasarkan tahapan sebagaimana diatur dalam Peraturan Presiden ini. Berdasarkan ketentuan tersebut, proses pengadaan tanah Jalan Tol Manado-Bitung dilanjutkan berdasarkan Undang-Undang No. 2 Tahun 2012 Jo. Perpres No. 71 tahun 2012 beserta perubahannya melalui tahapan perencanaan, tahapan persiapan, tahapan pelaksanaan dan tahapan penyerahan hasil.

\section{Tahapan Perencanaan}

Instansi yang memerlukan tanah bagi pembangunan untuk kepentingan umum membuat rencana pengadaan tanah berdasarkan Tata Ruang Wilayah, Prioritas Pembangunan yang tercantum dalam Rencana Pembangunan Jangka Menengah, Rencana Strategis, Rencana Kerja Pemerintah Instansi yang bersangkutan. Rencana pembangunan tersebut disusun dalam bentuk dokumen perencanaan yang dibuat oleh instansi yang membutuhkan tanah.

Dokumen perencanaan pengadaan tanah disusun berdasarkan studi kelayakan (Feasibility Study) yang didahului Pra Feasibility Study untuk menilai kelayakan proyek infrastrukur dengan mempertimbangkan sekurang-kurangnya aspek hukum, teknis, ekonomi, keuangan, pengelolaan risiko, lingkungan dan sosial. Dokumen Feasibility Study memuat hasil survey kelayakan sosial ekonomi, kelayakan lokasi, analisis biaya dan 
manfaat pembangunan bagi wilayah dan masyarakat, perkiraan harga tanah dan dampak lingkungan dan sosial. Prosedur penyusunan dokumen pengadaan tanah adalah sebagai berikut :

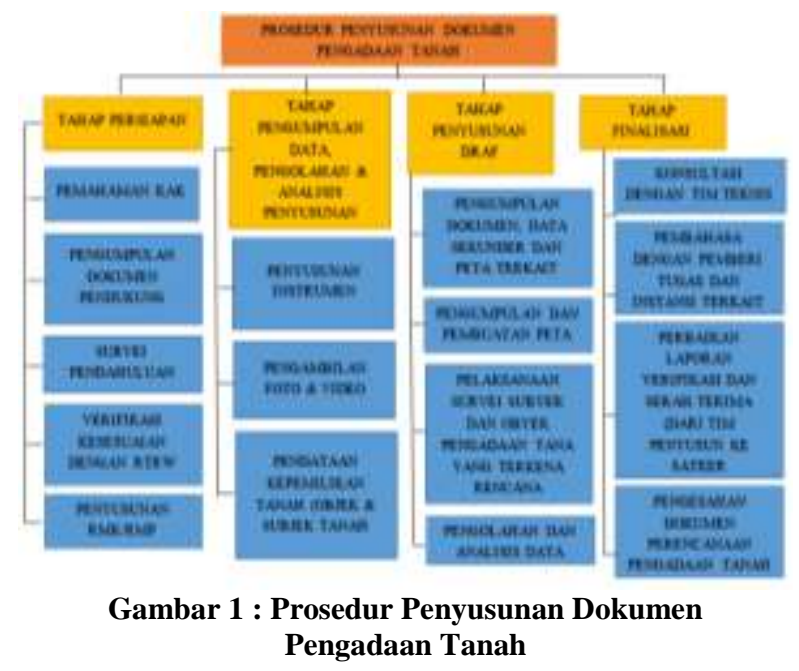

Dokumen perencanaan pengadaan tanah yang telah disahkan diserahkan kepada pemerintah provinsi, dan berdasarkan dokumen perencanaan tersebut pemerintah provinsi bersama instansi yang memerlukan tanah mempersiapkan pengadaan tanah.

\section{Tahapan Persiapan Pengadaan Tanah}

Berdasarkan dokumen perencanaan, Gubernur melaksanakan tahapan kegiatan persiapan pengadaan tanah dengan membentuk tim persiapan dan untuk kelancaran pelaksanaan tugas tim persiapan juga dibentuk sekretariat persiapan Pengadaan Tanah yang berkedudukan di sekretariat daerah provinsi. dalam waktu paling lambat 10 (sepuluh) hari kerja.

Tim persiapan bertugas :

a. Melaksanakan pemberitahuan rencana pembangunan

b. Melaksanakan pendataan awal lokasi rencana pembangunan

c. Melaksanakan konsultasi publik rencana pembangunan

Berdasarkan wawancara dengan sekretaris pelaksana pengadaan tanah Jalan Tol Manado-Bitung, tahapan persiapan diatas tidak dilaksanakan. hal ini juga ditegaskan Hukum Tua Maumbi bapak Jemi Kalengkongan yang mengatakan bahwa sewaktu menjabat hukum tua Desa Maumbi sejak tahun 2013 kelanjutan pengadaan tanah untuk pembangunan Jalan Tol Manado-Bitung sudah tidak dilaksanakan konsultasi publik tetapi sebelumnya pada tahap awal rencana pembangunan Jalan Tol Manado-Bitung sudah dilaksanakan sosialisasi beberapa kali di Kantor Hukum Tua Maumbi yaitu sekitar tahun 2010, dan pada tahun 2012 telah dibayarkan ganti rugi sebagian masyarakat yang menerima melalui proses musyawarah dengan Panitia Pengadaan Tanah berdasarkan nilai jual objek pajak.

Penulis juga mendapatkan data hambatan dan kendala yang dilaporkan Ketua Pelaksana Pengadaan Tanah Kepala Kantor Wilayah BPN Prop. Sulut yang dilaporkan tahun 2017 bahwa salah satu yang menjadi kendala keterlambatan pengadaan tanah Jalan Tol Manado-Bitung konsultasi publik tidak terlaksana dengan baik sehingga masyarakat terindikasi terkena kegiatan pengadaan tanah pembangunan Jalan Tol Manado-Bitung umumnya tidak mengetahui rencana pembangunan lebih khusus hal hal yang berkaitan dengan hak dan kewajiban pemilik tanah, tahapan dan proses pengadaan tanah, penilaian harga tanah, insentif yang akan diberikan kepada pemegang hak dan informasi lainnya untuk diketahui masyarakat terindikasi terkena pembebasan tanah. Konsultasi publik yang diatur dalam UU No. 2 tahun 2012 tidak diatur Peraturan presiden (Perpres) Nomor 36 Tahun 2005, dan dilakukan perubahannya Peraturan presiden (Perpres) Nomor 65 Tahun 2006.

Gubernur menetapkan surat keputusan Penetapan Lokasi dalam tahapan persiapan pengadaan tanah. Dalam hal setelah penetapan lokasi pembangunan masih terdapat keberatan, pihak yang berhak terhadap penetapan lokasi dapat mengajukan gugatan ke Pengadilan Tata Usaha Negara setempat paling lambat 30 (tiga puluh) hari kerja sejak dikeluarkannya penetapan lokasi. Pengadilan Tata Usaha Negara memutuskan diterima atau ditolaknya gugatan dalam waktu paling lama 30 (tiga puluh) hari kerja 
sejak diterimanya gugatan. Pihak yang keberatan terhadap putusan Pengadilan Tata Usaha Negara dalam waktu paling lama 14 (empat belas) hari kerja dapat mengajukan kasasi kepada Mahkamah Agung Republik Indonesia. Mahkamah Agung wajib memberikan putusan dalam waktu paling lama 30 (tiga puluh) hari kerja sejak permohonan kasasi diterima. Putusan pengadilan yang telah mempunyai kekuatan hukum tetap menjadi dasar diteruskan atau tidaknya pengadaan tanah bagi pembangunan untuk kepentingan umum. Gubernur bersama Instansi yang memerlukan tanah mengumumkan penetapan lokasi pembangunan untuk kepentingan umum dimaksudkan untuk pemberitahuan kepada masyarakat bahwa di lokasi tersebut akan dilaksanakan pembangunan untuk kepentingan umum.

Beberapa kali revisi penetapan lokasi pembangunan Jalan Tol Manado-Bitung merupakan salah satu penyebab keterlambatan proses pengadaan tanah, seharusnya apabila perencanaan dan pendataan awal dilakukan dengan baik sesuai dengan kaidah-kaidah teknis sebagaimana yang telah diatur maka penetapan lokasi yang merupakan suatu keputusan tentang kepastian keberlanjutan atas objek pembangunan yang telah direncanakan tidak akan mengalami beberapa kali perubahan. Menurut keterangan Bapak Samsudin Kono sebagai sekretaris Tim Pelaksana Pengadaan dimana saat itu menjabat Kepala Seksi Pengaturan Tanah Pemerintah di Kantor Wilayah BPN Provinsi Sulawesi Utara bahwa dalam rentang waktu penetapan lokasi pertama tahun 2015 sampai penetapan lokasi kedua tanggal 4 Januari 2016 pembayaran ganti rugi baru dapat dilaksanakan pada akhir tahun 2016. Terdapat ketidaksesuain titik koordinat terace jalan dengan keadaan dilapangan juga ditemui, titik koordinat diantara sungai tidak tersambung sehingga harus dilakukan revisi penetapan lokasi.

\section{Pelaksanaan Pengadaan Tanah}

Pengadaan tanah Jalan Tol ManadoBitung yang dimulai sejak tahun 2010 sampai dengan tanggal 31 Desember 2014 pembebasannya belum mencapai $75 \%$ sehingga proses pengadaan tanahnya yang semula berpedoman pada Peraturan Presiden (Perpres) Nomor 36 Tahun 2005, perubahannya Peraturan presiden (Perpres) Nomor 65 Tahun 2006 dilanjutkan sesuai UU No. 2 Tahun 2012 sebagaimana yang diatur dalam Perpres No. 99 Tahun 2012 Tentang Perubahan Kedua Atas Perpres No. 71 Tahun 2012, dalam pasal 123A (1) Proses pengadaan tanah sebagaimana dimaksud dalam pasal 123 ayat (3) yang belum selesai sampai dengan tanggal 31 Desember 2014, tetapi telah mencapai $75 \%$ dapat diperpanjang proses pengadaannya sampai dengan 31 Desember 2015, dan ayat (4) dalam hal proses pengadaan tanah sebagaimana dimaksud pada ayat (1) masih terdapat sisa tanah yang belum selesai sampai dengan tanggal 31 Desember 2015, pengadaannya diselesaikan berdasarkan tahapan sebagaimana diatur dalam Peraturan Presiden ini. Pelaksana pengadaan tanah adalah lembaga pertanahan, Kepala Kantor Wilayah Badan Pertanahan Nasional Provinsi Sulawesi Utara sebagai Ketua Pelaksana Pengadaan Tanah,

$$
\text { Pelaksana pengadaan tanah }
$$

sebagaimana dimaksud dibantu oleh Sekretariat Pelaksana Pengadaan Tanah yang bertugas untuk menyiapkan administrasi pengadaan tanah paling banyak 4 (empat) orang terdiri dari pejabat atau staf yang ditunjuk.

Tahapan Pelaksanaan Pengadaan Tanah bagi pembangunan untuk kepentingan umum Jalan Tol Manado-Bitung meliputi :

a. Penyiapan Pelaksanaan

Penyiapan pelaksanaan harus dituangkan dalam rencana kerja :

Rencana Kerja memuat paling kurang :

1. Rencana pendanaan pelaksanaan;

2. Rencana waktu dan penjadwalan pelaksanaan;

3. Rencana kebutuhan tenaga pelaksanaan;

4. Rencana kebutuhan bahan dan peralatan pelaksanaan; 
5. Inventarisasi dan alternatif solusi faktorfaktor penghambat dalam pelaksanaan; dan

6. Sistem monitoring pelaksanaan.

b. Inventarisasi dan identifikasi

Inventarisasi dan identifiksi subjek dan objek pengadaan tanah merupakan pekerjaan inti pelaksanaan pengadaan tanah Jalan Tol Manado-Bitung yang dikerjakan lembaga pertanahan dalam hal ini Kantor Wilayah Badan Pertanahan Nasional Provinsi Sulawesi Utara. Setelah proses penyiapan Ketua Pelaksana pengadaan tanah membentuk satgas A dan satgas B bersama satgas melakukan pemberitahuan kepada pihak yang berhak melalui lurah/ kepala desa atau nama lain. Pemberitahuan dapat dilaksanakan secara langsung dengan cara sosialisasi, tatap muka atau surat pemberitahuan setelah itu Satgas melakukan inventarisasi dan indentifikasi. Satgas A sebagimana dimaksud melakukan pengukuran dan pemetaan bidang per bidang tanah meliputi :

\section{Pengukuran batas keliling lokasi pengadaan tanah}

2. Pengukuran bidang perbidang

3.Menghitung, menggambar bidang perbidang dan batas keliling dan

4. Pemetaan bidang perbidang dan batas keliling dilakukan dengan cara mengukur dan memetakan tanah Pihak yang Berhak di dalam keliling bidang tanah atau terace (Pasal 10 Perkabpn No. 5 Tahun 2012)

Berdasarkan wawancara dengan ketua satgas A yang membidangi inventarisasi dan identifikasi data fisik penguasaan, pemilikan, penggunaan dan pemanfaatan tanah Bapak Adri Rotinsulu, SH proses pengukuran keliling lokasi pengadaan tanah dilaksanakan bersamaan dengan pengukuran bidang perbidang. Pengukuran bidang tanah objek pengadaan tanah mengikuti kaidah-kaidah pengukuran dan pemetaan kadastral meliputi perencanaan pengukuran, persiapan pengukuran, pelaksanaan pengukuran, pengolahan data dan pengolahan hasil pengukuran. Perencanaan pengukuran meliputi kegiatan rencana kerja persiapan pengukuran, rencana waktu pelaksanan pengukuran, kebutuhan tenaga ukur, kebutuhan peralatan yang diperlukan, kebutuhan dana. Persiapan pengukuran berupa persiapan administrasi, peralatan dan data bidang tanah lokasi dimaksud. Persiapan administarsi pengukuran dengan mempersiapkan surat tugas pengukuran dan penyampaian rencana waktu pelaksanaan pengukuran kepada pemerintah desa dan pihak pemilik tanah objek pengadaan tanah beserta dengan pihak pihak yang berkepentingan, yakni para tetangga yang berbatasan. Persiapan peralatan pengukuran dan data pengukuran yakni mempersiapkan alat ukur yang akan digunakan dan data pengukuran berupa petapeta pendaftaran yang ada dikantor pertanahan kabupaten minahasa utara yang menggambarkan bidang-bidang tanah yang sudah terdaftar/bersertipikat yang telah terpetakan dalam data base komputerisasi kantor pertanahan. Pelaksanaan pengukuran dilapangan oleh satgas A sesuai kaidah teknis pengukuran dan pemetaan kadastral harus didampingi pemohon dalam hal ini instansi yang memerlukan tanah dan pemilik tanah serta tetangga yang berbatasan. Implementasi pengukuran dilapangan tidak dapat dilakukan sesuai dengan perencanaan pengukuran, sejogjanya pengukuran dimulai dari $\mathrm{km} 0$ berurutan mengikuti terace sampai pada $\mathrm{km}$ terakhir, pengukuran pengadaan tanah Jalan Tol Manado-Bitung harus menyesuaikan dengan kondisi dilapangan terkait kehadiran pemilik tanah, tetangga berbatasan, pemerintah desa dan kepastian batas bidang tanah yang akan diukur. Pemilik tanah yang akan diukur dalam prakteknya kurang berperan aktif untuk menghadiri pelaksanan pengukuran padahal pemilik tanah berkewajiban untuk menunjuk batas bidang kepemilikan tanahnya. Tidak hadirnya pemilik tanah menyebabkan pengukuran tidak dapat dilaksanakan serentak, sehingga proses pengukuran tidak sistimatis tetapi harus lompat-lompat dan pengukuran harus tertunda-tunda. Kesadaran pentingnya fungsi kehadiran pemilik tanah maupun tetangga yang berbatasan saat pelaksanaan pengukuran dan pemetaan bidang tanah untuk keperluan pengadaan tanah tidak berbeda fungsinya pada pengukuran pemetaan kadastral yakni dalam rangka kepastian hukum terkait data fisik bidang tanah dimaksud. Asas 
kontradiktur delimitasi atau persetujuan tetangga yang berbatasan sebagaimana disyaratkan pada pelaksanaan pengukuran dan pemetaan dalam rangka pemberian hak juga berlaku untuk pengukuran dan pemetaan dalam rangka pengadaan tanah. Apabila pemilik tanah berserta tetangga berbatasan hadir pada pelaksanaan pengukuran, batas bidang tanah yang akan diukur terjamin kepastian hukumnya, proses pengukuran dapat berjalan dengan baik dan hasil pengukuranpun tidak akan mendapat komplain.

Tidak adanya patok batas bidang-bidang tanah dan batas pinggir objek pengadaan tanah yang akan diukur juga menjadi kendala keterlambatan penyelesaian pengukuran. Faktor penghambat lain berupa tidak terpasangnya tanda batas bidang-bidang tanah dan atau belum pastinya batas bidang tanah karena bermasalah antar pihak-pihak bertetangga. Penulis juga menemukan satu kasus dimana ada bidang tanah yang sudah di bayarkan ganti ruginya terhadap objek yang masih bermasalah, hal ini terkait dengan ketidak hadiran pemilik tanah pada saat pengukuran, dimana bidang tanah telah dibayarkan ganti ruginya tetapi kemudian hari mendapatkan keberatan dari pihak lain yang mengklaim bidang tanah tersebut adalah miliknya berdasarkan sertipikat hak milik. Hal ini terjadi dikarenakan patok batas bidang tanah yang sudah bersertipikat tidak terpasang dilapangan dan lebih memiriskan lagi pemilik tanah bersertipikat tidak mengetahui persis letak bidang tanah sesuai sertipikat dimaksud. Bidang tanah dimaksud pada proses penelitian ini belum dapat diselesaikan permasalahannya dan dalam proses mediasi oleh PPK dengan para pihak di Kantor Pertanahan Kabupaten Minahasa Utara.

Permasalahan lainnya terkait pelaksanaan pengukuran dalam rangka pengadaan tanah Jalan Tol Manado-Bitung terkait permasalahan pemilikan, umumnya untuk bidang-bidang tanah yanag belum bersertipikat.

Proses pengolahan data berupa penghitungan dan penggambaran bidang per bidang dan batas keliling dilaksanakan di Kantor Wilayah Badan Pertanahan Nasional Provinsi Sulawesi Utara. Secara umum pada proses penghitungan, penggambaran sampai pada pemetaan bidang tanah pihak yang berhak didalam batas keliling bidang tanah atau trace terkendala oleh karena batas keliling bidang tanah atau terace tidak terpasang patok tanda batas. Pemasangan patok tanda batas keliling bidang tanah atau terace berserta data awal terkait kepemilikan bidang-bidang tanah dan batas-batas kepemilikan yang terindikasi terkena pengadaan tanah Jalan Tol ManadoBitung idealnya telah dipersiapkan pada proses perencanaan dan persiapan.

Selanjutnya satgas B melaksanakan pengumpulan data paling kurang :

a. Nama, pekerjaan, dan alamat pihak yang berhak;

b. Nomor induk kependudukan atau identitas diri lainnya pihak yang berhak;

c. Bukti penguasaan dan/ atau kepemilikan tanah, bangunan, tanaman, dan atau benda yang berkaitan dengan tanah;

d. Letak tanah, luas tanah dan nomor identifikasi bidang;

e. Status tanah dan dokumennya;

f. Jenis penggunaan dan pemanfaatan tanah;

g. Penguasaan dan/ atau kepemilikan tanah, bangunan, dan/ atau benda lain yang berkaitan dengan tanah;

h. Pembebanan ha katas tanah; dan

i. Ruang atas dan ruang bawah tanah. (Pasal 16 Perkabpn No. 5 Tahun 2012)

Hasil iventarisasi dan identifikasi diserahkan oleh ketua satgas kepada pelaksanan pengadaan tanah dengan berita acara hasil inventarisasi dan identifikasi dengan lampiran daftar nominatif.

Menurut keterangan ketua satgas B, pengadaan tanah Jalan Tol Manado-Bitung Mareyke Lukas, SH bahwa "proses identifikasi dan iventarisasi terdapat beberapa kendala/ hambatan antara lain pemilik tanah tidak berada dilokasi sehingga kesulitan mendapatkan data yang dibutuhkan. Permasalahan pemilikan bidang tanah objek pengadaan tanah banyak bermunculan pada proses identifikasi dan iventarisasi dilaksanakan, sehingga dari hasil identifikasi dan iventarisasi sampai pada penyerahan hasil masih ada bidang tanah yang tidak diketahui pemiliknya. Adapun data subjek dan objek yang terindikasi akan terkena kegiatan pengadaan tanah ini, semestinya sudah 
ada dan diperoleh datanya pada tahapan perencanaan pengadaan tanah.

Berdasarkan wawancara dengan Pejabat Pembuat Komitmen Jalan Tol Manado-Bitung Bapak Weyni Paulce Davidson Mawey, ST dalam keterangannya menjelaskan bahwa "Keterlambatan data daftar nominatif dari satgas B khususnya terkait bangunan dan tanaman yang ada diatas tanah maupun dibawah tanah menjadi salah satu faktor keterlambatan proses pembayaran ganti rugi, Apracial tidak dapat melakukan penilaian apabila belum mendapatkan daftar nominatiif hasil inventarisasi dan identifikasi”.

Bapak Samsudin Kono sebagai sekretaris pelaksana pengadaan tanah Jalan Tol ManadoBitung menjelaskan bahwa "Sesuai UU No 2 Tahun 2012 data awal terkait kepemilikan bidang tanah yang terindikasi terkena kegiatan pengadaan tanah sudah diketahui dan disediakan instansi yang membutuhkan tanah pada tahapan perencanaan, karena pada tahapan perencanaan tidak dibatasi waktu".

Hasil inventarisasi dan identifikasi diumumkan di Kantor Kelurahan/ Desa, Kantor Kecamatan atau nama lain, dan lokasi pembangunan dalam waktu paling kurang 14 (empat belas) hari kerja. ((Pasal 17 angka (3) Perkabpn No. 5 Tahun 2012). Dalam hal pihak yang berhak keberatan atas hasil inventarisasi dan identifikasi dapat mengajukan keberatan kepada ketua pelaksanan pengadaan tanah dalam tenggang waktu pengumuman 14 (empat belas) hari kerja tersebut, apabila diterima dilakukan verifikasi ulang dan perbaikan terhadap peta bidang tanah dan/ atas daftar nominatif. Hasil inventarisasi dan identifikasi yang telah diumumkan dan tidak ada keberatan dari pihak yang berhak, menjadi dasar penentuan pihak yang berhak dalam pemberian ganti rugi.

\section{Penyerahan Hasil}

Mengacu pada Peraturan Presiden No. 71 Tahun 2012 tentang Penyelenggaraan Pengadaan Tanah Bagi Pembangunan Untuk Kepentingan Umum Jo. Perpres No. 40 Tahun 2014 Jo. Perpres No.99 Tahun 2014 Jo. Perpres No.30 Tahun 2015 Jo. Perpres No. 148 Tahun 2015 Ketua Pelaksana Pengadaan Tanah menyerahkan hasil Pengadaan Tanah kepada Instansi yang memerlukan tanah disertai data Pengadaan Tanah sebagaimana dimaksud dalam Pasal 110, paling lama 7 (tujuh) hari kerja sejak pelepasan hak Objek Pengadaan Tanah. Walaupun proses ganti rugi pengadaan tanah jalan tol Manado-Bitung berjalan sangat alot dan masih ada beberapa bidang tanah yang belum dibebaskan, kegiatan pembangunan fisik sudah dapat dilaksanakan karena bidang-bidang tanah yang berada disepanjang terace sudah dibebaskan dan secara keseluruhan sesuai data terakhir kemajuan pelaksanaan pengadaan tanah jalan tol Manado-Bitung tinggal menyisahkan sebagian kecil bidang-bidang tanah yang belum terbayarkan, yaitu yang berada dilokasi tambahan sesuai data progres pengadaan tanah.

\section{Mekanisme Ganti Rugi Pengadaan Tanah Pembangunan Jalan Tol Manado-Bitung di Kabupaten Minahasa Utara}

\section{Penetapan Penilai Tanah dan Pelaksanaan Penilaian Ganti Kerugian}

Ganti rugi pengadaan tanah bagi pembangunan untuk kepentingan umum Jalan Tol Manado-Bitung sejak tahun 2012 dimulai dari $0 \mathrm{~km}$ sd $7 \mathrm{~km}$ dilaksanakan oleh Panitia Pengadaan Tanah sebagaimana diatur dalam Peraturan Presiden No. 36 Tahun 2005, dan untuk $14 \mathrm{~km} \mathrm{sd} 39 \mathrm{~km}$ dan sisa dari $0 \mathrm{~km} \mathrm{sd} 7$ $\mathrm{km}$ yang tidak selesai dilanjutkan sesuai UU No. 2 Tahun 2012.

Proses yang berkaitan dengan pelaksanaan ganti rugi dimulai dari penetapan Penilai Tanah (Appraisal) oleh Ketua Pelaksana Pengadaan Tanah Kepala Kantor Wilayah Badan Pertanahan Nasional Provinsi Sulawesi Utara berdasarkan penunjukan dari Instansi yang memerlukan tanah. Penilai Pertanahan, adalah orang perseorangan yang melakukan penilaian secara independen dan professional yang mendapat izin praktek penilaian dari Menteri Keuangan dan telah mendapat lisensi dari lembaga Pertanahan (BPN). Dalam melaksanakan tugasnya Penilai atau Penilai Publik meminta peta bidang tanah, daftar nominatif dan data yang diperlukan untuk bahan penilaian dari Ketua Pelaksana 
Pengadaan Tanah. Penilaian ganti kerugian bidang per bidang tanah, meliputi :

a. Tanah;

b. Ruang atas tanah dan bawah tanah;

c. Bangunan;

d. Tanaman;

e. Benda yang berkaitan dengan tanah; dan/ atau

f. Kerugian lain yang dapat dinilai.

Berdasarkan wawancara dengan Darwadi yang bekerja bagian inpeksi lapangan di Kantor Jasa Penilai Publik SIH WIRAHADI \& REKAN salah satu KJPP yang melaksanakan penilaian pengadaan tanah Jalan Tol ManadoBitung, menjelaskan bahwa "KJPP SIH WIRAHADI \& REKAN penentuan nilai tanah dilakukan melalui survey harga pasar meliputi harga transaksi jual beli yang terjadi dalam kurun waktu tertentu dan dilokasi yang berdekatan dengan bidang tanah yang dinilai, data transaksi berdasarkan nilai pasar ini diambil sebanyak-banyaknya dan dengan ditentukan nilai rata-rata.

Penilaian bangunan sesuai dengan daftar nominatif satgas $\mathrm{B}$, bangunan apa saja terbangun diatas tanah dan dibawah tanah, antara lain rumah, pagar, sumur bor dan lainlain sesuai spektifikasi yang ada. Penentuan harga bangunan mengacu pada biaya teknis bangunan yang dikeluarkan Masyarakat Profesi Indonesia (MAPPI).

Penentuan nilai tanaman sesuai jumlah, jenis tanaman dan usia tanaman mengacu pada penetapan yang dikeluarkan pemerintah daerah. Nilai ganti rugi sesuai ketentuan UU No. 2 Tahun 2012 Terbagi dua yaitu Fisik antara lain sebagaimana tersebut diatas juga faktor non fisik meliputi biaya pindah, potensi kehilangan pekerjaan atau usaha, kerugian emosional (solatium), keterpaksaan, BPHTB dan lain sebagainya.

Besarnya nilai ganti kerugian berdasarkan hasil penilaian oleh Penilai disampaikan kepada Ketua Pelaksana Pengadaan Tanah dengan berita acara penyerahan hasil dijadikan dasar musyawarah untuk menetapkan bentuk ganti kerugian.

Nilai ganti kerugian Jalan Tol ManadoBitung dari hasil wawancara dengan apracial dan masyarakat penerima ganti, diatas rata-rata harga pasar dari beberapa transaksi jual-beli yang terjadi. Apabila dibandingkan dengan ganti rugi yang disepakati tahun 2012 berdasarkan musyawarah antara pemilik tanah dan panitia pengadaan tanah sesuai Peraturan Presiden Nomor 36 Tahun 2005, terdapat perbedaan signifikan. Sebagai contoh nilai ganti rugi bidang tanah yang berada dipinggir jalan dinilai oleh panitia pengadaan tanah dengan memperhatikan nilai jual objek pajak Rp. $250.000,-/ \mathrm{m}^{2}$, hasil penilaian dari Apracial tahun 2015 berdasarkan perbandingan harga pasar dinilai Rp. $1.200 .000 / \mathrm{m}^{2}$. Hal ini menunjukan penilaian yang dilakukan oleh apracial diatas rata-rata harga pasar dan mendekati nilai penggantian wajar.

Penentuan nilai ganti rugi oleh pemerintah berdasarkan peraturan perundangan yang berlaku dilaksanakan untuk memberikan ganti rugi yang layak, masih banyak juga keberatan yang diajukan masyarakat yang keberatan terhadap nilai ganti rugi.

\section{Musyawarah Penetapan Bentuk Ganti Kerugian}

Musyarwarah penetapan bentuk ganti kerugian dilakukan secara langsung untuk menetapkan bentuk ganti kerugian berdasarkan hasil penilain ganti kerugian oleh tim penilai. Bentuk Ganti Kerugian sesuai dengan peraturan adalah:

1. Uang;

2. Tanah pengganti;

3. Pemukiman kembali;

4. Kepemilikan saham;

5. Bentuk lain yang disetujui oleh kedua belah pihak.

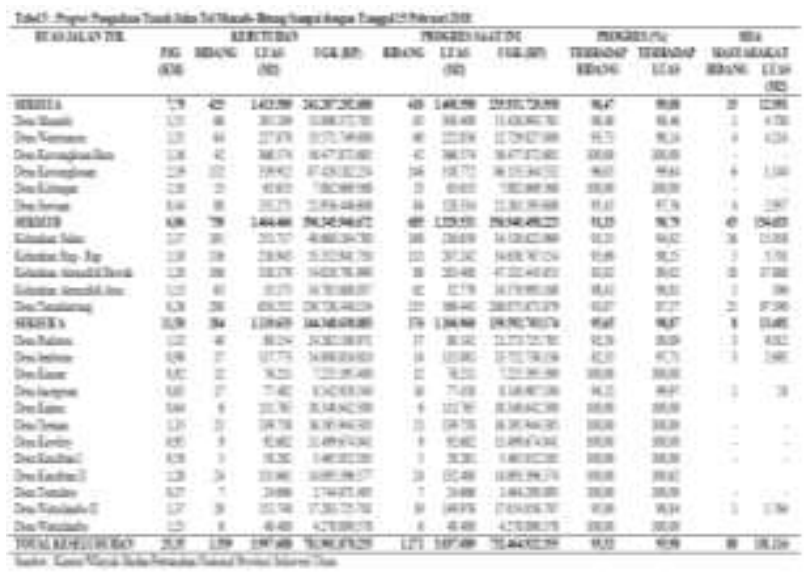


Berdasarkan Tabel 3 yang menggambarkan progress pengadaan tanah Jalan Tol Manado-Bitung diatas menunjukan kemajuan setelah proses musyawarah penetapan bentuk ganti rugi disepakati, dan ditindak lanjutkan dengan pembayaran uang ganti rugi dan atau bentuk lainnya. Data yang diperoleh Desa Maumbi masih tersisa satu bidang tanah yang belum dibayarkan ganti rugi karena masih bersengketa. Desa Watutumou empat bidang masih bersengketa, Desa Kawangkoan sementara proses musyawarah tiga bidang pelepasan hak tiga bidang proses konsinyasi satu bidang dan proses revisi peta bidang dan daftar nominatif satu bidang. Desa Suwaan proses konsinyasi satu bidang dan sengketa kepemilikan tiga bidang. Kelurahan Sukur sementara dalam proses revisi peta bidang dan daftar nominatif empat bidang, tidak diketahui keberadaan satu bidang, proses pelepasan hak empat bidang, rencana konsinyasi enam bidang, musyawarah satu bidang. Kelurahan Rap-Rap sementara proses revisi peta bidang dan daftar nominatif satu bidang, rencana konsinyasi empat bidang. Kelurahan Airmadidi Bawah dalam proses musyawarah 3 bidang, proses pelepasan hak satu bidang, proses kasasi satu bidang, revisi peta bidang dan daftar nominative empat bidang, konsinyasi 9 bidang. Kelurahan Airmadidi Atas dalam proses pelepasan hak satu bidang. Desa Tumaluntung dalam proses kasasi tujuh bidang rencana konsinyasi satu bidang, musyawarah enam bidang proses revisi peta bidang dan daftar nominatif satu bidang, proses pelepasan hak tujuh bidang, diluar terace tiga bidang dan dalam proses penilaian satu bidang. Desa Paslaten proses pelepasan hak satu bidang, rencana konsinyasi satu bidang dan yang berada diluar terace satu bidang. Desa Lembean rencana konsinyasi dua bidang, diusulkan tidak dimanfaatkan satu bidang. Desa Karegesan diusulkan tidak dimanfaatkan satu bidang. Desa Kauditan Satu tanah Pemprop satu bidang dan Desa Watudambo Dua diusulkan tidak dimanfaatkan satu bidang.

Lembaga Pertanahan melakukan musyawarah dengan pihak yang berhak dalam waktu paling lama 30 (tiga puluh) hari kerja sejak hasil penilaian dari penilai disampaikan kepada Lembaga Pertanahan untuk menetapkan bentuk dan/atau besarnya ganti kerugian. Berdasarkan hasil penilaian ganti kerugian. Hasil kesepakatan dalam musyawarah menjadi dasar pemberian ganti kerugian kepada pihak yang berhak yang dimuat dalam berita acara kesepakatan.

Dalam hal tidak terjadi kesepakatan mengenai bentuk dan/atau besarnya ganti kerugian, pihak yang berhak dapat mengajukan keberatan kepada pengadilan negeri setempat dalam waktu paling lama 14 (empat belas) hari kerja setelah musyawarah penetapan ganti kerugian. Pengadilan Negeri memutus bentuk dan/atau besarnya ganti kerugian dalam waktu paling lama 30 (tiga puluh) hari kerja sejak diterimanya pengajuan keberatan. Pihak yang keberatan terhadap putusan pengadilan negeri dalam waktu paling lama 14 (empat belas) hari kerja dapat mengajukan kasasi kepada Mahkamah Agung Republik Indonesia. Mahkamah Agung wajib memberikan putusan dalam waktu paling lama 30 (tiga puluh) hari kerja sejak permohonan kasasi diterima. Putusan Pengadilan Negeri/Mahkamah Agung yang telah memperoleh kekuatan hukum tetap menjadi dasar pembayaran Ganti Kerugian kepada pihak yang mengajukan keberatan. Dalam hal Pihak yang Berhak menolak bentuk dan/atau besarnya Ganti Kerugian, tetapi tidak mengajukan keberatan dalam waktu tersebut, pihak yang berhak dianggap menerima bentuk dan besarnya ganti kerugian.

Hasil wawancara dengan Bapak Rio Mangimpis, S.SiT sebagai salah satu penerima kuasa hukum dari Ketua Pelaksana Pengadaan Tanah Jalan Tol Manado-Bitung terkait permasalahan sengketa dan perkara menjelaskan bahwa " Perkara yang terkait Jalan Tol Manado-Bitung terbagi atas perkara keberatan ganti kerugian pengadaan tanah Jalan Tol Manado-Bitung dan perkara terkait objek pengadaan tanah".

Berdasarkan data yang diperoleh dari Penanganan Sengketa dan Perkara Kantor Wilayah Badan Pertanahan Nasional Provinsi Sulawesi Utara, terdapat beberapa sengketa yang diadukan pihak-pihak yang terkait, adapun sengketa terkait keberatan nilai ganti kerugian dan sengketa kepemilikan yang terdaftar di Pengadilan Negeri Minahasa Utara. 
Berdasarkan jumlah bidang tanah yang digugat terkait keberatan nilai ganti kerugian sebanyak di Pengadilan Negeri Airmadidi sebanyak tiga puluh empat perkara, delapan belas perkara dalam proses persidangan tiga perkara proses banding enam perkara telah dicabut dan dua perkara telah ada putusan.

Salah satu perkara gugatan ganti rugi oleh Penggugat Fedrik August Walewangko dengan nomor perkara : 131/ Pdt.G/2016/PN Arm Jo. No. 2076 K/PDT/2017 mengajukan gugatan kepada Kepala Kantor Wilayah Badan Pertanahan Nasional Provinsi Sulawesi Utara Selaku Ketua Pelaksana Pengadaan Tanah Pembangunan Jalan Tol Manado-Bitung. Dalam gugatannya disebutkan penggugat memiliki beberapa bidang tanah yang terletak di di Desa Tumaluntung Kecamatan Kauditan Kabupaten Minahasa Utara, didalam kebun terdapat tanaman-tanaman dan sebagian tanah penggugat akan dilewati pembangunan Jalan Tol Manado-Bitung dan telah ditetapkan nilai ganti rugi tanah oleh apracial seratus sebelas ribu rupiah per meter persegi, sedangkan menurut penggugat nilai pasar tanah kebun penggugat tujuh ratus ribu rupiah per meter persegi terdapat selisih harga nilai ganti rugi yang cukup besar. Penggugat memberikan data pendukung melalui keterangan para saksi bahwa terdapat beberapa bidang tanah yang berdekatan dengan tanah milik penggugat dan telah diganti rugi dengan nilai bervariasi. Terdapat kebun yang berbatasan dengan kebun penggugat yang diganti rugi tahun 2014 dibayarkan permeter tiga ratus lima puluh ribu rupiah sampai Sembilan Ratus tujuh puluh ribu rupiah permeter. Gugatan tersebut dikabulkan oleh Pengadilan Negeri Airmadidi tetapi ditolak ditingkat kasasi.

\section{Penitipan Ganti Kerugian}

Penitipan ganti kerugian dipengadilan adalah proses terakhir yang ditempuh jika kesepakatan terhadap besaran ganti rugi tetap ditolak oleh masyarakat sekalipun sudah berkekuatan hukum tetap.

Penitipan ganti kerugian dapat dilakukan apabila :

1. Pihak yang Berhak menolak bentuk dan/atau besarnya Ganti Kerugian berdasarkan hasil musyawarah dan tidak mengajukan keberatan ke pengadilan;

2. Pihak yang Berhak menolak bentuk dan/atau besarnya Ganti Kerugian berdasarkan putusan pengadilan negeri/Mahkamah Agung yang telah memperoleh kekuatan hukum tetap.

3. Pihak yang Berhak tidak diketahui keberadaannya; atau

4. Objek Pengadaan Tanah yang akan diberikan Ganti Kerugian:

a. sedang menjadi Objek perkara di pengadilan;

b. masih dipersengketakan kepemilikannya.

c. diletakkan sita oleh pejabat yang berwenang; atau

d. menjadi jaminan di bank.

Secara garis besar Konsinyasi adalah penawaran pembayaran tunai diikuti dengan penitipan di Pengadilan Negeri tempat di mana lokasi tanah untuk pembangunan tersebut berada, pelepasan objek pengadaan tanah;

Pelepasan Objek Pengadaan Tanah untuk Kepentingan Umum yang dimiliki pemerintah dilakukan berdasarkan kepada ketentuan peraturan perundang-undangan yang mengatur pengelolaan barang milik negara/daerah. Sedangkan Pelepasan Objek Pengadaan Tanah untuk Kepentingan Umum yang dikuasai oleh pemerintah atau dikuasai / dimiliki Badan Usaha Milik Negara /Badan Usaha Milik Daerah dilakukan berdasarkan UU No. 2 Tahun 2012 dan untuk Pelepasan Objek Pengadaan Tanah tersebut semua dilakukan oleh pejabat yang yang diberi pelimpahan kewenangan untuk itu.

Ganti Kerugian terhadap Pelepasan Objek Pengadaan Tanah tersebut diatas tidak diberikan, kecuali :

1. Objek Pengadaan Tanah yang telah berdiri bangunan yang dipergunakan secara aktif untuk penyelenggaraan tugas pemerintahan.

2. Objek Pengadaan Tanah yang dimiliki/dikuasai oleh Badan Usaha Milik Negara/ Badan Usaha Milik Daerah dan/atau

3. Objek Pengadaan kas desa. 
Mengenai Ganti Kerugian atas Objek Pengadaan Tanah sebagaimana dimaksud pada huruf a dan huruf c diberikan dalam bentuk tanah dan atau bangunan atau relokasi.

\section{KESIMPULAN DAN SARAN}

\section{Kesimpulan}

Hasil penelitian menunjukkan bahwa;

1) Proses pengadaan tanah Jalan Tol ManadoBidang mengacu pada UU No 2 Tahun 2012 jo. Perpres No. 71 Tahun 2012 meliputi tahapan : (a) Tahapan perencanaan dan (b) tahapan persiapan tidak terlaksana sebagaimana mestinya. Data awal terkait bidang-bidang tanah yang terindikasi terkena kegiatan pengadaan tanah tidak tersedia, terdapat beberapa kali revisi penetapan lokasi, dan konsultasi publik sebagai syarat untuk penetapan lokasi tidak dilaksanakan. (c) Tahap pelaksanaan oleh satgas A dan satgas B terkendala tidak adanya data awal, ketidak hadiran pemilik tanah, dan tidak terpasangnya patok batas bidang tanah dan batas keliling objek pengadaan tanah, juga pada titik terace tertentu terdapat perbedaan koordinat dengan patok terace yang ada dilapangan, kurangnya tenaga penilai bangunan dan tanaman yang professional, serta permasalahan terkait kepemilikan tanah. (d) Penyerahan hasil belum dapat diserahkan secara keseluruhan karena masih ada bidang-bidang tanah yang belum dibebaskan.

2) Mekanisme ganti rugi pada pengadaan tanah Jalan Tol Manado-Bitung sejak tahun 2012 sebagai berikut: (a) Penetapan Penilai Tanah oleh Ketua Pelaksana Pengadaan Tanah Pembangunan Jalan Tol Manado-Bitung berdasarkan penunjukan dari Instansi yang memerlukan tanah. Terdapat keterlambatan penyerahan nominatif terkait spesifikasi bangunan, benda-benda yang ada diatas/ dibawah tanah dan tanaman dikarenakan kurangnya tenaga yang berkompeten. (b) Musyawarah Penetapan Bentuk Ganti Kerugian, Banyaknya gugatan keberatan terhadap nilai ganti rugi dikarenakan dalam proses musyawarah sebatas memberitahukan nilai ganti rugi dan bentuk ganti rugi tetapi tidak menjelaskan menyangkut hasil penilaian oleh penilai tanah. (c) Penitipan Ganti Kerugian, karena adanya bidangbidang tanah yang bersengketa sehingga uang ganti kerugian harus dititipkan di pengadilan.

\section{Saran}

Kompleksnya permasalahan pelambatan proses pengadaan tanah Jalan Tol ManadoBitung penulis menyaranakan sebagai berikut :

1. Instansi yng memerlukan tanah berkoordinasi dengan Pemerintah Daerah mempersiapkan perencanaan pembangunan termasuk perencanaan pengadaan tanah dengan matang sesuai dengan kaidah-kaidah teknis yang ada mulai tahapan penentuan terace, kebutuhan dana, kebutuhan tanah, penyediaan data awal subjek dan objek bidang tanah terindikasi terkena kegiatan pengadaan tanah dan pelaksanaan konsultasi publik sebagaimana diatur dalam UU No. 2 Tahun 2012 serta peningkatan profesionalitas Pelaksana Pengadaan Tanah.

2. Perlu dipertimbangkan revisi aturan pengadaan tanah khususnya mengenai mekanisme musyawarah bentuk ganti rugi diperluas kewenangannya untuk memusyawarahkan nilai ganti rugi oleh Pelaksana Pengadaan Tanah atau tim khusus penanganan musyawarah nilai ganti rugi bagi pihak yang keberatan.

\section{DAFTAR PUSTAKA}

Badan Pusat Statistik Kabupaten Minahasa Utara. (2017). https: // minutkab .bps. go. id/. Diakses 21 April 2018.

Cresswel, J. (2013). Penelitian Kualitatif dan Design Riset. Memilih di Antara Lima Pendekatan. Yogyakarta: Pustaka Pelajar.

Harsono, B. (2003). Hukum Agraria Indonesia (Hukum Tanah Nasional). 
Munif A. 2011. Perlindungan Hukum Terhadap Hak-Hak Rakyat Atas Tanah

Nugroho, I. d. (2004). Pembangunan Wilayah, Perspektif Ekonomi, Sosial dan Lingkungan. Jakarta: LP3ES.

Pemerintah Republik Indonesia. (2006). Peraturan Presiden Repulik Indonesia No 65 Tahun 2006. Perubahan Atas Peraturan Presiden Nomor 36 Tahun 2005 Tentang Pengadaan Tanah Bagi Pelaksanaan Pembangunan Untuk Kepentingan Umum. Jakarta.

Rustiadi, S. (2011). Perencanaan dan Pengembangan Wilayah. Jakarta: Crestpent Press dan Yayasan Pustaka Obor Indonesia.

Sirojuzilam, M. (2010). Regional: pembangunan, perencanaan dan ekonomi. Medan: USU Press.
Soimin S. 2001. Status Hak dan Pembebasan Tanah. Edisi Kedua. Jakarta: Sinar Grafika.

Sumardjono, M. (2015). Dinamika Pengaturan Pengadaan Tanah di Indonesia .

Tarigan. (2012). Perencanaan Pembangunan Wilayah. Jakarta: Bumi Aksara.

UU No 2 Tahun 2012. Pengadaan Tanah Bagi Pembangunan Untuk Kepentingan Umum. Http: // www. bpn. go. id/ PUBLIKASI/ Peraturan-Perundangan/ Undang-Undang/ undang - undang nomor - 2 - tahun - 2012 - 876 . Diakses 21 April 2018.

Warokka TD, Zulkifli, Simaniburuk M. 2006. Sengketa Tanah: Bentuk. 